Page 315-326. ISBN: 978-602-6 988-75-1

Web Jurnal Online: jurnal.unmuhjember.ac.id

By: Anwar Sadat, Hastuti

Resilience Of Fisheries A Sustainable Bahari Village

\title{
RESILIENCE OF FISHERIES A SUSTAINABLE BAHARI VILLAGE
}

\author{
ANWAR SADAT ${ }^{1}$, HASTUTI ${ }^{2}$ \\ Email : anwarsadat685@gmail.com ${ }^{1}$ \\ UniversitasMuhammadiyahButon ${ }^{1}$ \\ UniversitasMuhammadiyahButon $^{2}$
}

\begin{abstract}
This research is more of a problem solving, comprehensive, meaningful, complete and sustainable related to the resilience of fisherman groups in Bahari Village, Sampolawa Subdistrict, South Buton Regency. The problems were experienced by the Bahari Village Fishermen Group include 1). Fishermen communitydepended on the season, so they had difficulty in earning a living because of extreme weather condition, rising fuel prices, and sudden changes in wind direction. The fishing community of the Bahari Village in Sampolawa Sub-District still has low resilience. 2). The main external interference or pressure in fishing activities. 3). The low income of the Bahari Village fishermen community because the marine fishing technology generally still used the traditional equipment. This study aims to solve the problems posed by fishermen groups in helping to create peace, comfort and increase good resilience so that groups of fishermen are able to live in community life. The solutions offered in this activity will empower fishermen groups through learning and social adaptation while increasing fisherman resilience and building sustainable communities Resilience of BahariVilage fishing groups can be seen from the ability to learn to live in change and uncertainty, the ability to develop various ways to reorganize and renewal, the ability to combine various kinds of knowledge, and the ability to create opportunities for self-organization. As an initial step, observation and identification of problems encountered by partners have been carried out. in this activity carried out with the method of Education and Training. Technically the method used is the Survey Method and assistance. Direct observation is intended to obtain an overview of the area, situation, and conditions, and to verify the data obtained from the results of interviews with the existing reality.
\end{abstract}

Keywords: Resilience, Fishermen Groups, Sustainable 


\section{INTRODUCTION}

Bahari as a village in Subdistrict of Sampolawa, South Buton Regency is a coastal area, which has various potentials to improve the level of the economy and income of the community. If it is properly managed, the potential of Bahari Village will provide a great contribution to the sustainable development of that area. The main livelihood of the community is fisherman. The obstacles engaged in their work as a fisherman deal with climate change, overfishing, and exploitation of marine resources so that those make them difficult to get the sea catches.

The most susceptible area affected by climate change is coastal area because it directly borders to the sea and lowland areas around it. When sea level rises above land heights, sea water will inundate the plains (Marfiraniet al., 2012). Moreover, coastal area is also susceptibleto other effects of climate change such as rising temperatureof oceanand allowing the extreme weather. The increase of temperatureallows the damage of coral reefs which affects the quantity reduction of fish in the ocean. The rapid and unpredictable cycle of weather change causes the susceptible increase, especially for fishing communities that are very dependent on weather condition and coastal ecosystem. The life of fishermen tightly depands on natural condition, as it is evidenced by the increase of fishermen income during the fish season (Pradana, 2014). In the rising sea wave, the intensity of fishermen's sea is reduced, thus the amount of income of fishermen is obviously decreased. Various factors such as the weather uncertainty, the extreme weather condition, the rising sea surface temperature (sea surface temperature-SST), the fluctuations of fuel prices and the changes of wind direction, reduce the productivity level of fishermen. Climate change also affects the distribution of sea catch and distribution of fish in the sea, while the rising fuel prices affects fishermen's opportunity to catch fish along with a shift in the spread of fish that are constantly changing due to climate change. The Chairpersonof Fishermen in Bahari Village, Mr. Laode Burhan, said that the uncertain weather and sea conditionreduces the fish catch. Certainly, it affects the daily income.

When the weather is good, Laode Burhan is able to earn between Rp 100,000 to Rp 800,000. When the harvest season arrives, his income increases to IDR 2,000,000. However, when the weather was bad, he only earns 200 thousand rupiah a day for his wife. The size of the fishing boat here is rather small, when the weather is bad, I doubt to go fishing. The catch of fishermen is also various, some looking for small fish, other looking for squid, and etc. According to Laode Burhan, the heat of the sun also affects the quality of drying. Small fish is not sold. "In the dry season, small fish in wet condition is sold at Rp10 thousand per kilogram, if it is dry, it will reach Rp30 thousand," he said. Similarly, La Sira, a fisherman in Bahari said the difficulty of finding fish, squid and shrimp when the weather is uncertain. Moreover, the boat was damaged by high waves and a few winds a while ago. Squid is sold to collectors Rp.15 thousand per kilogram, if he sold byhimself, the price will reach Rp25 thousand, in dry condition. If the dry season is enough to dry a daylong, in this rainy season it takes more than two days. 
Figure 1. Resilience of Fishermen inBahari Village
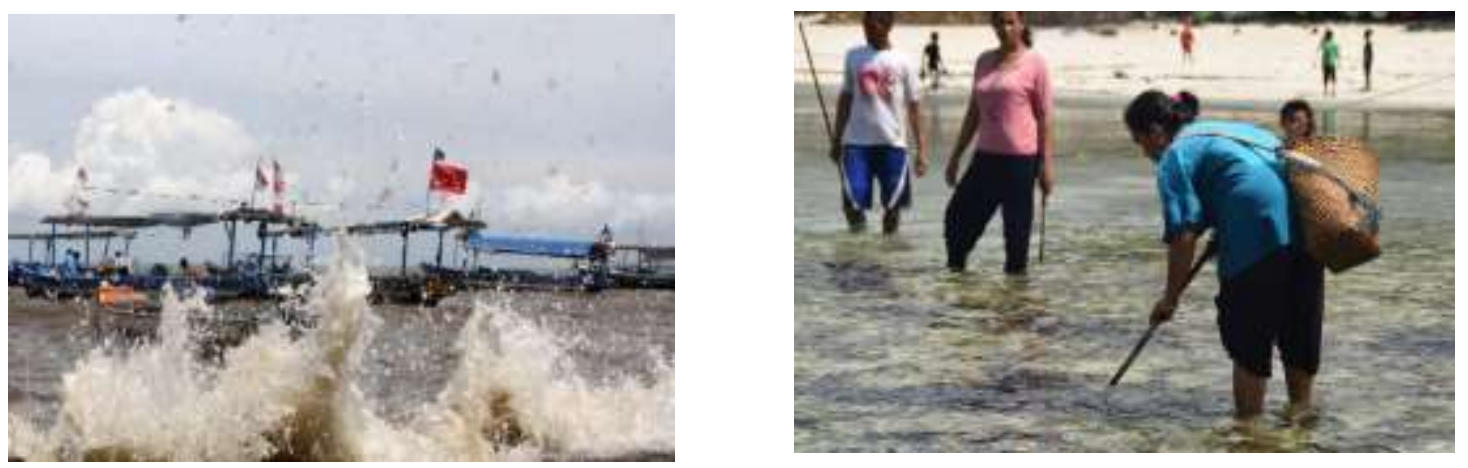

The Fishermen community in Bahari catches fish using spears or machetes. By a spear ready to be killed, several local people were chasing fish in the shallow sea. By a single pounding of the hand, the tip of the spear pierces the fish. Then, he pulls out the spear and then put the fish into the fishing line so that it doesn't come off. The activity of catching fish with a spear is called "Pindokoa" Tradition that conducted by the local people of Bahari Village, Sampolawasubdistrict, South Buton Regency. This tradition has been around for hundreds of years and is still preserved by the people of Wapulaka, BahariVillage. This tradition is usually held when the weather is bad and fishermen have difficulty getting fish in the sea. "This is a pindokoa activity, most of local people is a fisherman, if the weather is bad this is not going to sea. So the water (sea) recedes, this is how we find fish here, this is called pindokoa, "said a resident of Bahari Village, $\mathrm{Mr}$ Efendi.

The problems encounterby the fishermen community in Bahari Village, so that the fishermen need to create a mechanism of resilience to survive or adjust to the changes that occur and return to their original condition. The intended change is the disasters such as climate change which reduces the income of fishermen. VanBreda (2001) defines community resilience as the ability of the community to build, maintain, or regain the level of community capacity expected in the face of positive difficulties and challenges. Everyone has difficulties or a problem and no one lives in the world without a problem or difficulty. So that a general question can be drawn, namely how is the Resilience of the Village Marine Fisheries Group sustainable?

\section{PROBLEM}

Based on the description above, several problems encountered by fishermen community inBahari Village namely:

1) The dependence on the season.

In the fishing season,the dependence is largely sustained by marine resources. Moreover, for some days, they may not be able to go to sea due to the weather that is not possible, in other words, fishermen community inBahari Village have low resilience. The extreme weather affecting the fishermen being unable to go to sea can occur at certain times. The decrease in catch was also triggered by the increase in 
Proceeding ICOGISS 2019

Page 315-326. ISBN: 978-602-6 988-75-1

Web Jurnal Online: jurnal.unmuhjember.ac.id

By: Anwar Sadat, Hastuti

Resilience Of Fisheries A Sustainable Bahari Village

fishing efforts occurred, as a result of the increase in the number of fishermen and the number of fishing gears, so that the catch from each fishing effort decreased.

2) The low income of fishermen communityin Bahari Village because the technology of marine fishing in general still uses traditional equipment.

Based on these problems, what is encountered by Bahari Village fishermen groups are: sea conditions that are full of risk of danger and uncertainty, various types of behavior patterns in fish and marine biota of fisheries resources, marine environments that appear homogeneous but apparently heterogeneous, fisheries and marine resources is the property of shared wealth and is open accses, rapidly decaying marine and fishery products, volatile fish prices, and the exploratory attitude faced by fishermen from outside parties. These problems are categorized as disasters that can reduce the income of fishermen so that the effect of poverty on fishermen in Bahari Village

\section{RESEARCH METHOD}

To realize this activity, an implementation technique was arranged so that the activities were conducted according to the schedule, being structured and on target. Based on the above, a solution is to overcome the problems encountered by fishermen with several stages, namely library research, survey to find the root of the problems of fishermen community in the field. As an initial step, observation and identification of problems encountered by partners have been conducted with the resilience model of fisherman community on two aspects, namely the potential risk (exposure and sensitivity) and adaptability. This method is qualitative research under the the constructivism paradigm, a paradigm that emphasizes research must be conducted in the natural world as the real to capture natural phenomena as they are and thoroughly without interference and manipulation of researchers (Denzin\& Lincoln, 2000).Data collection wascolleted by hermetic method and dialectics using participant observation techniques, focus group discussions, in-depth interviews, and literature studies. Informants were selected purposively representing community socio-political-economic-ecological information and the process of change from time to time and the diversity of characteristics of the fishing community in Bahari Village.

The data analysis method used was a qualitative data analysis method consisting of two stages. The first analysis of qualitative data was the search results of general statements about the relationship between various categories of data to build conceptual understanding of reality based on the findings of empirical data. Includes analysis of the data produced from direct observations participating, FGDs and in-depth interviews during research. Also analysis of data which was data about past and contemporary events related to the social phenomena under study. Second, the categorization of data was conducted in accordance with the formulation of the questions posed to facilitate interpretation, selection and explanation in the form of analysis descriptions. Direct observation was intended to obtain an overview of the region, situation and conditions, and to verify the data obtained from the results of interviews with the existing reality. The implementation phase of the activity can be described as follows:

1) Conduct literature surveys and field surveys. 
2) Exposure level.

3) Sensitivity level.

4) Adaptability.

This study used a qualitative approach through interviews with parties who understand the problem such as fishermen (boat owners / skipper, crew, boat captain, small boat fishermen) who have experience, and the Fisheries and Marine Service of South Buton Regency. Qualitative data analysisdeals with axial coding, timeline analysis and triangulation of data from various sources then synthesizing and drawing conclusions.

\section{DISCUSSION}

\subsection{Understanding local fishermen}

The fishing community at the study site felt ecological changes in the past 5 years, including the rising sea level, the intensity of storms and high waves, the changes in fishing ground and chaos in the fishing season. Before interaction with researchers, fishermen had never been exposed to intense information about climate change. Some claimed that they had heard through the mass media but they were not interested or did not explained scientifically. Understanding of environmental change, is notcaused by scientific knowledge of climate change. Basically the changes occurring were not realized directly considering the process taken place in a long time and is not sporadic. The researcher captured that understanding based on adaptation changes in fishermen's livelihoods and analyzing the available adaptation options. The following is a description of fishermen's understanding of the ecological changes associated with climate change in related scientific studies. Fishermen in general felt a sea level rise of approximately 3 meters. In some locations, in the past few years fishermen anchoredtheir boat to the side of the house because the previous was behind the house was now flooded with sea water. In another location, the community's yard which was used as a boat for boating is now flooded with sea water. In another location fishermen made 'para-para' as a place to raise the boat to avoid the waves crashing while not in use. At present, almost all beaches close to residential areas had been built with wave retaining walls which in local language are called talit. Fishermen argued that if there was no sea talit, now they arrived at home or on the road. Fishermen also told how the talit built by many governments had collapsed because they were unable to resist the blow of wavewhich were "increasingly evil" according to them. Along the Village road which was on the shoreline there were also a lot of asphalt that had been peeled and hollow with puddles of sea water in the middle.

Fishermen felt that strong winds accompanied by tidal waves in recent years were more common. The government had built 'talit' to withstand waves of waves but according to them, sometimes waves crashed over the existing taro. In Bahari Village, the position of the talit is in front of the houses of the residents towards the beach so that the houses of the residents were located between the taro and the sea. Fishermen claimed that they have to be more careful of the previous times because of the higher risk of fishing. Not infrequently fishermen even chose not to go to sea to avoid disaster risk.Fishermen used the term 'angintidakkaruan(the wind is not broken), 'anginndaadahidup' (the wind is not alive) or 'anginancursekali' (the wind is very bad) to describe the unpredictable wind direction 
and high waves with expressions "ombakjahat" (evil wave) describing waves that it can't be handled anymore. Encountering extreme weather as illustrated by the phrase "matiakal" (mind is dead)or "kalautberarticarimati"( going to sea means you want to die). Fishermen felt the waves could not be handled because of their relatively new direction and characteristics for their old knowledge and experience. Indeed, the fishermen in Bahari Village had been known as great seafarers who are "good at" overcoming the waves because of tuna fishermen, they were faced with the character of fishing harvested during the choppy season and its position far enough to the middle of the sea. The type of waves in the middle of the sea according to fishermen at this time was different, no longer the same as the types of waves they hadknown.theexpression "saya tidak tahu angin itu arah dari mana" ( I don't know where the wind comes from), illustrated that the current wind and wave patterns are completely different. Besides, the expression "biar ikan makan bagaimanala saya tidak berani. Itu perahu bisa terbalik" (however the fish eats, I don't dare. That boat can be reversed) illustrated that change goes beyond their knowledge and navigation skills.

In addition to changes in the wind season, fishermen also felt the shift of fish harvest season. So far, to determine the time of fishing and fishing ground locations, fishermen were guided by the 'season calendar' which is written by 'elders' namely old fishermen who were considered very experienced and had knowledge of the vast sea. In the past 5-7 years, uncommomnly, the predictions were irrelevant to conditions in the middle of the sea.At present, fishermen trusted the collectors more. Weather information owned by collecting traders usually derived from observing the actual sea conditions obtained on a network. The knowledge of local fishermen about the 'tanoar'of tuna fish occurred in April to May. June to early September was a bad season. Nowadays tanoar sometimes went back and forth for 1-2 months. In the last 3 years (2015-2018) even more fishermen did not go to sea due to the seasonal chaos and the intensity of the storms that continued to increase.

Another thing that has changed according to fishermen is the position of the fishing ground that is getting to the middle of the sea. If about 5 years ago fishermen only needed to travel for about 1 hour to find tuna fish and start fishing, now they had to spend at least 3 hours to reach the fish farm. It's with the same boat and engine. Fishermen understood the character of tuna fish as fast swimmers, but their knowledge had always been able to accurately predict the location of fish and cut off its habitat. No more now.

\subsection{Exposure Level}

Based on the results of interviews, some technical difficulties in going to sea were caused by the climate change, namely: (1) the risingSea level. The occurrence of surface expansion of coastal or coastal area were increasingly approaching the settlement of fishing communities from year to year. This prompted the Regional Government to build a dam to prevent the entry of seawater into the residential areas. (2) the extreme weather caused damage to boats and threatened the safety of fishermen. (3) the Courage and personal mentality in the sea. The risk of fishermen's life puts the personality of the fisherman to be a more careful person and takes into account many considerations. The indication is seen by the phenomenon of more fishermen taking breakin fishing if the 
Page 315-326. ISBN: 978-602-6 988-75-1

Web Jurnal Online: jurnal.unmuhjember.ac.id

By: Anwar Sadat, Hastuti

Resilience Of Fisheries A Sustainable Bahari Village

season is bad. "The west season (rainy season) causes a lot of big waves, in the year (2017), it never left for 5 days to the beach because of high waves. Now even if you go to sea you have to go as far as 8 miles (10 km from the shoreline) to get fish. "The following is the result of an interview with Fisherman Mr. Kasim:

"Sekitar 5 tahun lalu, cuaca masih bisa ditebak. Sekarang cuaca tidak bisa diprediksi, harusnya bulan ini (bulan Juni) angin timur. Kemarin angin laut (angin utara) enak untuk melaut, kalau timur otomatis nganggur, kalo timur airnya butek (keruh). Harusnya angin timur bulan tujuh ini, tapi masih berganti-ganti, kadang timur, kadang laut, kadang barat. Kondisi cuaca yang sulit ditebak dan berganti- ganti tersebut menyulitkan keputusan melaut dan mengganggu usaha saya menangkap ikan di laut" (Hasil wawancara nelayan Bahari Village,2018).

Translation:

"it was about 5 years ago, the weather was still predictable. Now, the weather is unpredictable, this month (June) should be east wind. Yesterday was north wind so it is good for fishing, but if it is east wind, I automatically do nothing, if the east wind comes, the water will be cloudy. It should be east wind in this seventh month but it is changed. Sometimes it is east wind, sometimes west. The weater is unpredictable and changeable so it affects the fishing decision and interfere my sea catch." (the result of interview with a fisherman inBahari Village,2018).

Exposure is the extent to which climate change intersects with patterns of life and people's livelihoods and ecosystems (IPCC, 2007). The determinants of exposure are current climate trends (seasons), climate-related events, climate estimates, and community data and scientists. The community in Bahari Village SampolawaSubdistrict, South Buton Regency has experienced several things related to climate change as follows: The period of the monsoon and the rainy season changes: shifts for more than one month, the signs of the season coming all over are not the same, the ability of the community to predict the season is no longer reliable. Bad weather events that damage property and threaten the safety of lives take place almost every year. The area was covered by seawater because of the highest tides or sea level rise showed an increase every year in the last 5 years.

\subsection{Sensitivity Level}

Sensitivity of fishermen based on interviews with fishermen includes: (1) Fishermen felt longer barriers in one season (2) the increase of climate change impact causes the increase threats in life safety and fishermen and fisherman families anxiety. (3) Fishermen's livelihood activities were disrupted. (4) The response of the public trust system, that fades in obeying the prohibition on going to sea on Friday. The sudden change of weather put pressure on the fishermen who then responded by using a fleet of motor boats having higher cruising power. This fact can be seen from the statement of fisherman Mr. La Ode Burhan as follows:

"Cuaca mempengaruhi paling utama usaha saya sebagai nelayan. Bapak saya nelayan dari memakai perahu dayung belum ada mesin, masih menggunakan alat tradisional. Kalau Kapal Motor besar dengan alat tangkap Gillnet itu lebih enak, jangkauannya luas. Jadi jika disini angin barat yang merupakan cuaca yang tidak mendukung untuk menangkap ikan tetapi di luar sana seperti di perairan Laut Banda 
Page 315-326. ISBN: 978-602-6 988-75-1

Web Jurnal Online: jurnal.unmuhjember.ac.id By: Anwar Sadat, Hastuti Resilience Of Fisheries A Sustainable Bahari Village

tidak angin barat, Kapal Motor besar dengan alat tangkap Gillnet dapat menjangkau sehingga tetap dapat beroperasi menangkap ikan pada kondisi cuaca tersebut" (Wawancara dengan Nelayan, 2018)

Translation:

The weather affects the main job of me as a fisherman. My father was a fisherman who used boat without machine, used traditional tool. The motor boat with the catching tool Gillnet is easier, wide range. If here is west wind is unsupported weather to catch the fish but in other area like in Banda is not west wind. Motor boat with gillnet can reach it so that we can catch the fish in every kinds or weather.

The results of the sensitivity analysis of the community at the research location are presented in table 1 . The results of the sensitivity assessment of the fishing community in the study locations as described in table 1 are summarized high. In general, the cause of this high exposure is the character of the community that depends only on one resource, namely marine resources.

Tabel 1 the sensitivity level of fishermen inBahari Village

\begin{tabular}{|c|l|l|}
\hline No. & Effects of Climate Change and Bad Weather & $\begin{array}{l}\text { Mortality Level } \\
\text { Range }\end{array}$ \\
\hline 1 & $\begin{array}{l}\text { Changes in climate conditions are felt in livelihood } \\
\text { activities (livelihoods) }\end{array}$ & Big \\
\hline 2 & $\begin{array}{l}\text { In one season, community livelihood activities are } \\
\text { hampered }\end{array}$ & $\begin{array}{l}\text { One season or } \\
\text { more }\end{array}$ \\
\hline 3 & $\begin{array}{l}\text { Effect of changing climate conditions on health and peace } \\
\text { of mind of the community }\end{array}$ & Quite big \\
\hline 4 & $\begin{array}{l}\text { Effect of changes in climate conditions on fisheries } \\
\text { natural resources }\end{array}$ & Big \\
\hline 5 & $\begin{array}{l}\text { Bad weather events that have caused damage to property } \\
\text { and accidents in the last five years }\end{array}$ & Several times \\
\hline Effect of Overall Climate Change & High \\
\hline
\end{tabular}

Matrix 1. Assessment of Potential Impacts

\begin{tabular}{|c|c|c|c|c|}
\hline \multicolumn{5}{|c|}{ Sensitivity } \\
\hline \multirow{4}{*}{ 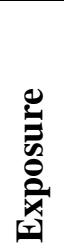 } & & Almost Nothing & Medium & Severe \\
\hline & Small to none & small & Small & medium \\
\hline & Some & small & Medium & high \\
\hline & Almost all & medium & High & high \\
\hline
\end{tabular}

This condition illustrates the overall losses that might occur if climate conditions change. The high potential impact was based on the argument that the level of exposure covers almost all fishing communities and the sensitivity of fishermen and natural resources to the impact of climate change in a high category.

\subsection{Adaptability Ability}

The forms of technical and social adaptation were made by fishermen consist of: (1) Replacing a faster boat engine from $20 \mathrm{Pk}$ to $40 \mathrm{Pk}$ to overcome high waves, (2) Speeding up fishing time, before sunrise to get more fish or lobster catches, (3) Finding 
Page 315-326. ISBN: 978-602-6 988-75-1

Web Jurnal Online: jurnal.unmuhjember.ac.id By: Anwar Sadat, Hastuti

information on catchments by establishing social relations with fishermen who are outside Bahari Village (4) Collecting sea fishing to reduce risks when at sea.

The results of the assessment of the fishing community adaptability inBahari Village in the study location were concluded to be high or good with various arguments as outlined in table 2. After knowing the level of exposure, sensitivity and adaptability as the component sets the level of vulnerability, an assessment of the level of vulnerability can be made fishing community in the research location. The scoring systematics was guided by the community vulnerability assessment matrix (matrix 2). The potential impact of climate change was high but it is balanced by adaptive capacity which was also high so it caused the vulnerability of the fishing community system categorized as being moderate. In other words, the impact of climate change was still in the coping range of the Village community system which means that the community was still able to overcome it and as a result fishermen had not experienced significant losses.

Table 2. Level of Ability and reference to general conditions for Marine Fishermen Village

\begin{tabular}{|c|c|c|}
\hline No & Feature Reference & Level \\
\hline 1 & $\begin{array}{l}\text { Communities had togetherness, mutual cooperation habits, have } \\
\text { leaders and a group of people who work for the interests of the } \\
\text { Village, the habit of deliberation in making joint plans, and good } \\
\text { values in managing the environment }\end{array}$ & High / Good \\
\hline 2 & $\begin{array}{l}\text { The community had the expertise, ability and cooperation as well } \\
\text { as strong motivation to overcome the problem of changing climate } \\
\text { conditions for sources of livelihood, including livelihoods or other } \\
\text { options, and overcoming bad weather problems that result in } \\
\text { property damage and life safety. }\end{array}$ & High / Good \\
\hline 3 & $\begin{array}{l}\text { The community had the ability to build relationships and good } \\
\text { cooperation with outside parties (NGOs, private sector, local } \\
\text { government) }\end{array}$ & Medium/Enough \\
\hline 4 & $\begin{array}{l}\text { The environment of a healthy living place, diverse natural } \\
\text { resources, and healthy and sufficient water sources }\end{array}$ & High / Good \\
\hline 5 & $\begin{array}{l}\text { Having knowledge and experience in dealing with previous } \\
\text { environmental changes }\end{array}$ & High / Good \\
\hline 6 & $\begin{array}{l}\text { The community had a strong social network that is a source of } \\
\text { social support }\end{array}$ & High / Good \\
\hline \multicolumn{2}{|c|}{ Value of Capability Level in Community Adaptation (Average) } & High / Good \\
\hline
\end{tabular}

Matrix 2. Community Vunerability Assessment

\begin{tabular}{|l|l|c|c|c|}
\hline \multicolumn{5}{|c|}{ Adaptability } \\
\hline \multirow{3}{*}{$\begin{array}{l}\text { Potential } \\
\text { impact }\end{array}$} & The highest & Low & Medium & High \\
\cline { 2 - 5 } & High & High & High & Medium \\
\cline { 2 - 5 } & Medium & High & Medium & Medium \\
\hline & Low & Medium & Medium & Rendah \\
\hline & Low & Low & Low \\
\hline
\end{tabular}


Page 315-326. ISBN: 978-602-6 988-75-1

Web Jurnal Online: jurnal.unmuhjember.ac.id

By: Anwar Sadat, Hastuti

Resilience Of Fisheries A Sustainable Bahari Village

\subsection{Adaptation Strategies: Reducing Vunerability, Increasing Resilience}

Adaptation is a real act of adjusting the physical and social environment system with several principles of approach to deal with the possible negative impacts of climate change. The level of the system's ability to deal with the consequences of climate change was described as an interval of tolerance to the magnitude, intensity and rate of climate change. Referring to the concept of interval tolerance, adaptation was needed to widen the tolerance interval (coping range) to overcome the increasingly high vulnerability triggered by the negative impacts of climate change (Figure 4). Conditions of the tolerance interval was wider than the vulnerability of the climate system, itwas resilient to climate change. The detailed resilience of the group in this study was understood as the ability of the community to overcome disturbances or changes and maintain adaptive behavior. In the context of climate change, resilience was the ability to respond to the effects of climate change while continuing to function regularly.

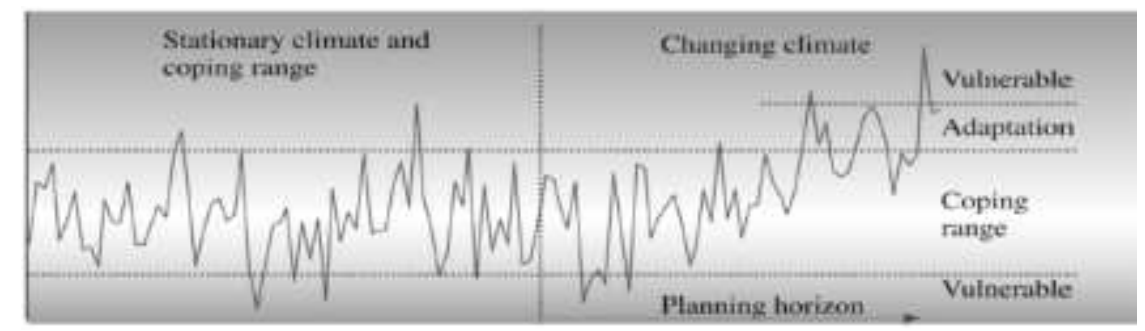

Figure 4. Concept of the relationship between interval tolerance, vulnerability, climate change, and adaptation (Source: Jones et al. 2004

Anticipating sea level rise, a number of adaptation strategies was undertaken. First, build 'talit' that could directly resist sea level rise, tidal waves and rob. The existing assets were all built by the government through several projects. Second, fishermen made para-para, which was the storage of boats while not fishing on the sea, anticipating the tidal waves that had the potential to land boats. Para-para was made between taro and shore, from small logs which are resistant to sea water. Fishermen did not plant mangrove trees as adaptation was commonly done to prevent the impact of rising sea water and tidal waves because according to them, the beach in the Bahari Village was rocky so the trees could not grow properly. The impact of climate change was received by fishing communities which provoked some reactive adaptations, including (1) implementing a seasonally adaptive strategy. This strategy was a form of adaptation carried out by fishermen if the surrounding waters experienced a famine. Since ancient times, fishermen believed that their ancestors had made a strategy to catch up with the season even though they only used traditional landlords. What is different from now is that in the past, the knowledge and calculation of the seasons applied with the form of the seasonal calendar became an accurate guideline, now it is more often inaccurate. Fishermen's estimates of the season and place for harvesting tuna were often more wrong than true. At present, fishermen trusted the collectors more. Weather information that was owned by collecting traders usually came from observing the actual sea conditions obtained on a network. Each collector usually had fishermen in every area in South Buton District and the development of mobile phone technology that had reached remote areas facilitates the dissemination of that information; (2) fishermen form a fishing operation group. Realizing the greater risk of fishing and anticipating more frequent weather predictions and missing fishing ground, fishermen undertook fishing operations in groups of 3-4 boats. The advantage of fishing in groups wass that 
Page 315-326. ISBN: 978-602-6 988-75-1

Web Jurnal Online: jurnal.unmuhjember.ac.id

By: Anwar Sadat, Hastuti

Resilience Of Fisheries A Sustainable Bahari Village

the number of fishermen involved, various kinds of knowledge and experience were combined to determine the type of bait tuna fish were interested in, the location of tuna, and predict the threat of storms while in the middle of the ocean. Arrest groups are also intended as an action to anticipate storms that were often unexpected to help each other in the middle of the sea; (3) in the condition of all fishing ground that they know to be inaccessible either due to famine or due to unpredictable weather, fishermen prefer not to carry out fishing activities and switch to working on off fishing activities. This section discusses findings from the results of data collection and analysis. These findings include the impact of climate change on fishermen, the phenomenon of adaptation by utilizing capture fish production technology, an overview of government policy support, and the synthesis of challenges in the use of technology to adapt to the effects of variability and climate change in Bahari Village Sampolawa District, South Buton Regency. Head of South Buton District Marine and Fisheries Agency Mr. H. La Ode Taatlan stated the same thing as the impact of climate change:

"Perubahan iklim di Bahari Village Kabupaten Buton Selatan yang mengakibatkan terjadinya perubahan lokasi fishing ground menjauhi bibir pantai. Hal ini juga diakibatkan karena adanya pencemaran di daerah pesisir."Cuaca yang tidak menentu dan sulit diprediksi dalam 4-5 tahun terakhir ini diakui para nelayan sehingga menyebabkan mereka tidak melaut dalam beberapa hari. Lokasi penangkapan ikan yang biasanya didaerah pesisir, berpindah lebih jauh kelaut lepas. (Hasil Wawancara dengan Kepala Dinas, 2018)

Translation:

"the climate change in bahari village, south buton regency affect the change of fishing ground stay away from the beach. It is caused by coastal pollution." The unpredictable weather and difficult to predict in the last 4-5 year is admitted by the fishermen so that they did not go fishing for few days. The catch fish area is in coastal, moving so far to high seas.

\section{CONCLUSION}

From the results of the research, it is concluded that the resilience of fishermen groups in Bahari Village SampolawaSubdistrict, South Buton Regency could be said to be resilient fishermen from the effects of climate change. The impact of climate change did not result in disruption of family functions in political allocation, integration allocation and allocation of solidarity. Only the differentiation of roles and economic allocations was disrupted but the adaptation of the family structure succeeds in returning it to a stable or functional situation. Based on the findings on the effects of climate change and the level of vulnerability and in order to maintain the functionality of the fishermen's family structure, it is recommended to revitalize local knowledge about season and fishing activities in the context of the development of modern knowledge in the field of climatology and fishing technology, strengthening access to local institutions in order increase the resilience of the family livelihood system, and increase the human capital of the fishermen family members, especially skills outside the sea. In addition, it is very important to maintain basic family values such as love, respect, commitment, responsibility and family togetherness in facing difficult times. 
Page 315-326. ISBN: 978-602-6 988-75-1

Web Jurnal Online: jurnal.unmuhjember.ac.id

By: Anwar Sadat, Hastuti

Resilience Of Fisheries A Sustainable Bahari Village

\section{References}

Arifin. 2010. Pola Spasial Kerentanan Bencana Alam. Dapat diunduh dari: http://lib.ui.ac.id/file?file=digital/20277564-T\%2029015Pola\%20spasial-full\%20text.pdf

Helmi A, Arif S. 2012. Strategi Adaptasi Nelayan Terhadap Perubahan Ekologis. Diunduh dari: http://journal.ui.ac.id/index.php/humanities/article/viewFile/1494/1296

Jones, R.G.. Noguer, M., Hassell, D.C., Hudson, D., Wilson, S.S., Jenkins, G.J. and Mitchell, J.F.B., 2004: Generating high resolution climate change scenarios using PRECIS, Met Office Hadley Centre, Exeter, 40pp. Available online at http://precis.metoffice. com/docs/PRECIS_Handbook.pdf

Jordan E, Amy JW. 2012. Measuring Community Resilience and Recovery: A Content Analysis of Indicators. . ASCE 2012: 2190-2199 Dapat diunduh dari:

https://mcedc.colorado.edu/sites/default/files/Measuring\%20Community\%20Res ilience\%20and\%20Recovery \%20A\%20Content\%20Analysis\%20of\%20Indicat ors.pdf

Kulig JC, Edge DS, Dana SE, Joyce B. 2008. Understanding community ressiliency in rural communities through multidimethod research. Journal of Rural and Community Development. Dapat diunduh dari: http://www.jrcd.ca/viewarticle.php?id=181

Lebel L, Anderies JM, Campbell B, Folke C, Hatfield-Dodds S, Hughes TP, Wilson J. 2006. Goverment and the capacity to manage resilience in regional Socilaecological system Dapat diunduh dari: http://www.ecologyandsociety.org/vol11/iss1/art19/

Lekotompessy HS, Natsir N, Arief AA. 2010. Strategi Adaptasi Nelayan Pulau-Pulau Kecil terhadap Perubahan Ekologi. Dapat diunduh dari: http://pasca.unhas.ac.id/jurnal/filesB8e41a786da110597359750867c6c4c7.pdf

Marfiani R, Ira A. Pergeseran Mata Pencaharian Nelayan Tangkap Menjadi Nelayan Apung di Desa Batu Belubang. Dapat diunduh di: http://eprints.undip.ac.id/37618/1/014 IRA ADIATMA.pdf

Pradana PP. 2014. Analisis Faktor-Faktor yang Mempengaruhi Kesejahteraan Keluarga Nelayan Buruh Desa Puger Wetan Kecamatan Puger Kabupaten Jember. Dapat diunduh dari:

http://repository.unej.ac.id/bitstream/handle/123456789/61276/Agung\%20Putra \%20 Pradana\%20-\%20090810101053_1.pdf?sequence $=1$

Subair, Lala M K, Soeryo A, Bambang P. 2014. Resiliensi Komunitas dalam Merespon Perubahan Iklim Melalui Strategi Nafkah (Studi Kasus Desa Nelayan di Pulau Ambon, Maluku). Dapat diunduh dari: http://repository.ipb.ac.id/handle/123456789/69903

Thompson JA, Tracie S, LaDon S. 2012.Increasing Risk Awareness: The Coastal Community Resilience Index. Dapat diunduh dari: http://www.joe.org/joe/2012august/tt5.php

Tompkins EL dan Adger WN. 2003. Building resilience to climate change through adaptive management of natural resources. [Laporan penelitian]. Norwegia, University Of East Anglia Dapat diunduh dari http://www.tyndall.ac.uk/sites/default/files/wp27.pdf

VanBreda AD. 2001. Resilience Theory : A Literature Review.. Dapat diunduh dari : http://vanbreda.org/adrian/resilience/resilience_theory_review.pdf 